\title{
John the Baptist and The Kingdom of God
}

\section{By Knox Chamblin}

'I tell you this: never has there appeared on earth a mother's son greater than John the Baptist, and yet the least in the kingdom of Heaven is greater than he.'

'Ever since the coming of John the Baptist the kingdom of Heaven has been subjected to violence and violent men are seizing it' ${ }^{9}$ (Mt. I I : I I f.). ${ }^{1}$

'Until Fohn, it was the Law and the prophets: since then, there is the good news of the kingdom of God, and everyone forces his way in' (Lk. I6: I6).

A. The Ministry of John according to Matthew II: 12 and Luke I6: I6

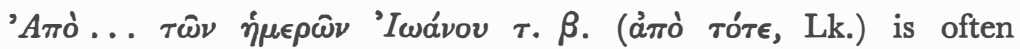
understood to mean 'from the conclusion of the ministry of John.' 2 However, there is good reason to believe that Matthew intends to include the ministry of the Baptist in the time when the Kingdom

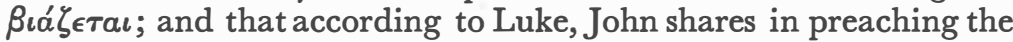
good news of the Kingdom.

Grammatically, åmó may be inclusive. ${ }^{3}$ Three other Matthean passages where the construction $\dot{a} \pi \dot{o} . . . \check{\epsilon} \omega s$ occurs, are instructive: 20:8: 'the last' are among those receiving wages. 23: 35: Abel's death is the first instance of 'innocent blood spilt'. I : I7: When Abraham is numbered first, David comes fourteenth (verses 2-6); likewise from Jeconiah to Jesus (verses 12-16). ${ }^{4}$ Accordingly ảmò ...

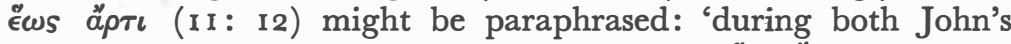
ministry and mine'. W. G. Kümmel understands ë $\omega$ s ă $\rho \tau \imath \iota$ 'to express that the $\beta \iota a ́ \zeta \epsilon \sigma \theta a \iota$ and $\alpha^{\prime} \rho \pi a ́ \zeta \epsilon \iota \nu$ is merely a provisional happening

${ }^{1}$ Quotations are from the NEB, unless otherwise noted.

2 E.g. H. Ridderbos on Mt. I I : 12 : 'We shall have to understand [ámó] in an exclusive and not in an inclusive sense. John is on the threshold, he leads on from the old to the new dispensation; he himself still belongs to the old period' (The Coming of the Kingdom (Pres. \& Reformed, 1962), p. 54). According to $\mathrm{H}$. Conzelmann, 'Luke tries to see John in the line of all the other prophets. He stands before Jesus as the last of the prophets, not as an authentic eschatological figure.' The period of the Law and the prophets 'comes to its close with John, the greatest of the prophets, but his status does not carry him beyond it, for even he does not proclaim the Kingdom of God' (The Theology of St Luke (Faber \& Faber, I960), p. IOI).

${ }^{3}$ So D. Daube, The New Testament and Rabbinic Fudaism (Athlone Press, I956), pp. 285 f.; and E. Bammel, 'Is Luke I6, I6-18 of Baptist's Provenience?', Harvard Theological Review, LI, I958, p. I03, n. I4.

4 Yet if David is counted as the first of the second series, verses 6-1 1, Jeconiah comes fifteenth. 
which will come to an end ... [The] limit of є̈ $\omega s$ ă $\rho \tau \iota$ will be the future dawn of the consummated Kingdom of God when it appears [in power].' 5 But it is more natural to apply ä $\rho \tau \iota$ specifically to the time of Jesus' ministry, rather than to the entire period between John and the End.

According to Matthew I I : 16-I9 (par. Lk. 7: $3^{1-35)}$ the ministries of John and Jesus, though markedly different, are directed to the same end-to declare the wisdom of God to their generation. ${ }^{6}$ Matthew 2 I : 23-27 (par. Lk. 20: I-8) implies that God is the source of both Jesus' and John's authority.

John stands within the Eschaton: His function is essentially that of a prophet (i.e. to announce, and prepare the people for, things to come), ${ }^{7}$ and yet in this very work prophecies of the Old Testament (= 'the Law and the prophets') are being fulfilled. ${ }^{8}$ In Luke it is the beginning of John's ministry (not Jesus') that is carefully dated in terms of world history ( $3: \mathrm{I} \mathrm{f}$.). ${ }^{9}$ By all indications, in Acts I: 22

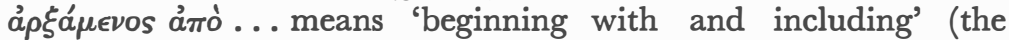
baptism of John). ${ }^{10}$ In Acts I3: $23 \mathrm{ff}$. the announcement of the coming of Jesus precedes the summary of John's work; $c f$. Mark I : I-8. John indeed stands within the Time of fulfilment, if on the threshold of its brightest Day. ${ }^{11}$

In Matthew 3: 2 John announces: 'Repent, for the kingdom of heaven is at hand' (Rsv). G. H. Dodd (e.g.) believes these are words

${ }^{5}$ Promise and Fulfilment (S.C.M., I957), p. I 24. In Kümmel's judgment the verse speaks of violence against the Kingdom (p. I22).

${ }^{6} C f$. TWNT, VII, p. 516; and J. Schniewind, Matthäus (Das Neue Testament Deutsch), on i $1: 19 b$.

7 Mt. I I : 9; 14:5; 2 I : 26; Lk. I : 76; 7:26; $20: 6$.

${ }^{8}$ Mt. 3: 3; I I: 10; I 7: I1-13; Lk. I: 68-79; 3: 4-6; 7: 27. G. Bornkamm comments on Mt. I I : I 2: 'John is herewith raised above all the prophets before him ... He is no longer the herald of the future only, but already belongs himself to the time in which the promise is being fulfilled' (Jesus of Nazareth (Hodder \& Stoughton, I963), p. 5I). Thus John is 'far more than a prophet' (Mt. I I : 9 f.). Cf. O. Cullmann, The Christology of the New Testament (S.C.M., I959), pp. 24-28. The Fourth Evangelist places the words of Is. 40: 3 on the Baptist's lips, 'and in this he may be closer to the facts than the Synoptics' (see C. H. Dodd, Historical Tradition in the Fourth Gospel (Cambridge University Press, I963), pp. 252 f.).

${ }^{9}$ As J. M. Robinson notes, The Problem of History in Mark (S.C.M., 1957), p. 23, n. I.

${ }^{10}$ So J. M. Robinson, ibid., p. 22. He adds: 'Since neither Luke nor the earlier tradition presents the twelve as having been with Jesus from the baptism on, Acts I : 22 must be looked upon as evidence of some theological interest in "beginning with John", (p. 22, n. 3). See also Lk. 23: 5; 24: 47; Acts 8: 35 .

${ }^{11}$ In the words of Bornkamm: Between John and Jesus 'and their preaching there is a difference like that between the eleventh and the twelfth hours' (op. cit., p. 67). Accordingly Peter can speak in Acts 10: 37 of "what happened lately ... starting from Galilee after the baptism proclaimed by John'. J. M. Robinson notes that Acts I : 22 may be co-ordinated with Mk. I : I ff., and Acts 10: 37 with Mk. I: I4 (op.cit., p. 22). 


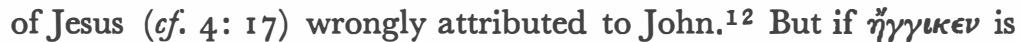
rendered 'is near', and not 'has arrived', the saying is perfectly suitable on John's lips: $c f .3: 7-12 .{ }^{13}$ The Kingdom is simply nearer at 4: I 7. Furthermore, it may be inferred that at this point John's preaching has helped to determine Jesus' own message. ${ }^{14}$ In Luke John is never expressly said to have preached 'the Kingdom of God', but he is said to have 'evangelized' (3: 18) - and what is the preaching of $3: 7-17$, if not a promise of, and a summons to prepare for, the Kingdom?

If $\beta \iota c^{\prime} \zeta \epsilon \tau a \iota$ (Mt. I I : I2) is interpreted as a passive in malam partem,

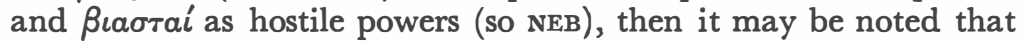
John suffers violence on account of his preaching (4: I 2; I4:3-I I ; I 7: I $2 \mathrm{f}$.). However, for reasons that cannot be given here, it is perhaps better to interpret the verb as a middle, and the noun as men eager to seize the Kingdom for themselves ( $c f$. NEB margin). ${ }^{15}$ But does the Kingdom begin to 'force its way forward' as early as the ministry of John?

To be sure, the Kingdom begins to 'come' in the fullest sense only with Jesus (Mk. I : I4 f.; Lk. 4: I8-2 I). John is not reported to have performed any mighty works such as gave evidence during Jesus' ministry that the Kingdom had really come (Mt. I I : 5; I 2: 28). But he does announce, with singular authority (as the latter-day Elijah), that the Kingdom is coming. His is the function of the 'herald' (Mt. I I: Io) whose message is so self-authenticating as to need no corroborative miracles. His preaching has a widespread and profound effect (Mt. 3: 5; 2 I : 26; Lk. 3: 10-I5; cf. Josephus, Antiq. XVIII. $5: 2)$. If this earnest response is not a case of people's 'seizing upon' (Mt. I I : I2) or 'forcing their way into' (Lk. I6: 16) the Kingdom, it does at least indicate their readiness to do so when given the opportunity. What accounts for the people's thanksgiving in Luke 7:29, if not the realization that their favourable response to John's message prepares them for entry into the Kingdom ( $c f$. Mt. 2 I : 3 I f.) ?

12 The Parables of the Kingdom (Nisbet, I 94I), p. 48.

13 Part of the considerable amount of historical truth which Prof. Dodd detects in the Fourth Gospel's record of the Baptist's preaching, is that John 'aroused a widespread conviction that a divine interposition was impending, ... placed the ideal figure of the Messiah fully in the centre of the picture of the crisis ... and declared that the Messiah was already $\mu$ éroos vं $\mu \omega \hat{\nu}$, though incognito, thus intensifying the expectancy' (Historical Tradition, pp. $300 \mathrm{f}$.).

14 So Prof. E. A. Russell in his Tyndale Biblical Theology Lecture, 'John the Baptist and Jesus', delivered July I5, I964, and to be published.

${ }_{15}$ By all accounts, Lk. I6: $16 \mathrm{~b}$ and Mt. I $1: 12$ are based on the same saying of Jesus, the Matthean version more nearly representing the original. But on this

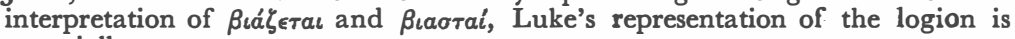
essentially correct. 


\section{B. The Position of John according to Matthew I I : I I and Luke 7:28}

Thus John the Baptist preached the good news of the Kingdom's coming and suffered for it. But does John actually belong to the Kingdom he proclaims? The interpretation of A. Plummer is that of many: John 'was not within the Kingdom which he announced.' 16 W. Marxsen says of John according to Luke: 'He himself does not belong within the Kingdom; he stands before it.' 17 Yet Matthew I I : I I and par. must be otherwise understood.

According to the Synoptics, the Kingdom of God is both present and future. Insofar as the Kingdom 'comes' in the present, it comes with the ministry of Jesus. The response required of Jesus' hearers is that they receive the Kingdom (Mk. I0: $15 ; c f . \mathrm{Lk}$. I9: 12, 15； 12: 32) -in other words, gladly accept and humbly and trustfully submit to the Herrschaft of God here and now. ${ }^{18}$

But references to 'entering into the Kingdom (or life)' or being 'in the Kingdom' (Reich) appear to apply exclusively to the future: see especially Matthew 8: I I (par. Lk. I3: 28 f.); I3: 43; I8: I, 3 (cf. verses 8 f. and par.); 20: 2 I ; 26: 29 (par. Mk. I4: 25; cf. Lk. 22: I6); Luke 22: 30. In Matthew 7: i $3 \mathrm{f}$., the gate stands at the beginning of the narrow road, but 'life' at the end. In view of such evid-

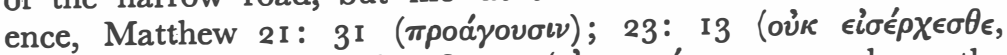

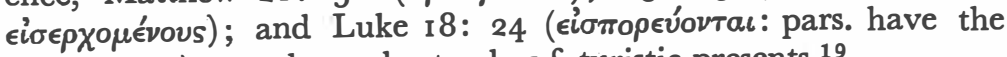
future tense) must be understood as futuristic presents. ${ }^{19}$

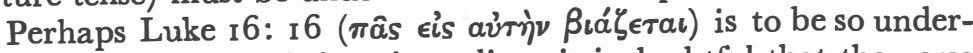
stood. Yet for all Luke's universalism, it is doubtful that the verse means, 'All will (violently) enter the Kingdom.' The reference is to the present, the people's longing for the Kingdom, and their consequent readiness to seize upon a promise or sign of its coming. $\pi$ âs will include persons who respond eagerly to Jesus' preaching, but who nevertheless misunderstand his words, read into them something alien to their intention, or in time of testing fall away (Lk. 8: I3). It will include persons most zealous to 'enter the Kingdom', but who are unwilling in the end to 'receive the Kingdom' on Jesus' terms (see I $3: 23-30$, especially verse 24 ; and I I : $5^{2}$ ).

Thus according to the Synoptics' presentation of Jesus' teaching,

16 Commentary on Mt. I I : I I.

17 Der Evangelist Markus (Vandenhoeck \& Ruprecht, 1956), P. 31 .

18 This will invariably mean hearkening to and obeying the words of Jesus (e.g. Mt. 7: 21, 24). The only ones of Jesus' hearers to 'receive the Kingdom' are those who 'receive the word' he declares (Mk. 4: 20; $f$. verse 16 and pars.).

${ }_{19}$ See J. Jeremias, The Parables of Jesus (S.C.M., 1963), p. 125, n. 46. In Mt. 13:

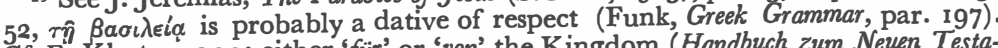
Cf. E. Klostermann: either 'für' or 'von' the Kingdom (Handbuch zum Neuen Testament, in loc.). 
it is possible to receive, and thereby become a citizen of, the Kingdom of God here and now; but to 'enter into' and be 'in' the Kingdom only hereafter. Both aspects are found in Mark 10: I5: 'I tell you, whoever does not accept the kingdom of God like a child will never enter it.' $C f$. Phil. 3: 20 f.; I Pet. 2: I I.

On this showing, Matthew I I : I I b refers to the future Kingdom; and it is unthinkable that John would be excluded from this - just as it is unthinkable that the Patriarchs and the Prophets would be excluded (Mt. 8: I I ; Lk. I3: 28).

How does John stand with reference to the present manifestation of the Kingdom, in the ministry of Jesus? As portrayed in the Synoptics, the Baptist is the kind of person who is to possess the Kingdom ( $c f$. Mt. 5: 3-10). Matthew. I I: 8 ( $c f .3: 4)$ suggests that he was among the 'poor' whom Jesus came to evangelize (I I : 5). ${ }^{20} \mathrm{He}$ longed to see right prevail (Lk. 3: 7-I 7). As the latter-day Elijah, he was the 'peacemaker' ${ }^{21} \mathrm{He}$ was persecuted 'for the cause of right' (Mt. 5: 10; $c f .2 \mathrm{I}: 32 ;$ Mk. 6: 20). He would urge his hearers to repent (Mt. 3: 2 ; Lk. 3:3) only after having done so himself. ${ }^{22}$

There are indications in the Gospels that John acknowledged Jesus to be the Messiah, before his imprisonment. If the Lukan birth narratives are read as the history they purport to be, it may be inferred that John in his youth learned that Jesus was Messias designatus. When Jesus comes to John for baptism, Matthew reports, 'John tried to dissuade him. "Do you come to me?" he said; "I need rather to be baptized by you", (3: I4). 'This' (verse I 7) suggests that the word from heaven was directed to John (perhaps among others). But the singular 'he saw' (3: 16; par. Mk. I : ro) does not necessarily mean that Jesus is the only one to witness the descent of the Spirit ( $c f$. Jn. I : 32-34); or 'Thou' (Mk. I : I I ; par. Lk. 3:22) that he is the only one to hear the voice. However, only in the Fourth Gospel does John expressly identify Jesus with Messiah (I: I5, 29-36, 4I). The absence from the Synoptics of such a confession, remains a puzzle. ${ }^{23}$

${ }^{20}$ Cf. W. Sattler, 'Die Anawim im Zeitalter Jesu Christi', in Festgabe für A. Fulicher (Mohr, I927), p. 8; and on the 'poor' of Qumran, S. Légasse, 'Les Pauvres en Esprit et les 'Volontaires" de Qumran', NTs, VIII, 1962, pp. 336-345; and J. Dupont, in Neutestamentliche Aufsätze: Festschrift für J. Schmid (Pustet, 1963), pp. 53-64.

${ }^{21}$ See Sir. 48: ro; and Strack-Billerbeck Kommentar III, pp. 8 f.

22 Probably one reason for the restricted diet of John and his disciples (Mk. I : 6; Lk. 7: 33; 5: 33) was to demonstrate their repentance and humility before God. Cf. C. H. H. Scobie, John the Baptist (S.C.M., I 964), pp. I 39 f.

${ }^{23}$ See C. H. Dodd, Historical Tradition, pp. 290-30 I. 
Jesus' own work begins in full only after John is imprisoned. ${ }^{24}$ If, when Jesus' work has reached a later stage, it appears to John that Jesus is accomplishing less than Messiah would accomplish, the question of Mt. I I : 3 is quite understandable. This, I believe, is the reason for John's question. ${ }^{25}$ His earlier belief in Jesus as Messiah now wavers. $\mathrm{He}$ is in danger of finding Jesus a stumbling-block ( I I : 6).

How John reacted to the message of Jesus ( I I : 4-6) can only be conjectured. Perhaps his uncertainty persisted, but he is more likely to have made a forthright decision about Jesus. M. Goguel thinks it was unfavourable:

'The way in which Matthew and Luke relate the sending of the disciples of John to Jesus seems to imply that, in the mind of the narrators, John was not convinced. If the tradition had thought the opposite, the evangelists would not have failed to say that after having rendered the homage of a prophet to Jesus John would have rendered it a second time, founded this time upon the work which had been accomplished. Thus John persisted in his point of view. After Jesus had left him John only saw in him an unfaithful disciple and almost a renegade.'26

But as Goguel acknowledges, 'the interest of the story centres in Jesus and not in John the Baptist'. ${ }^{27}$ And had the narrators really thought of John in the way Goguel imagines, would they have added verses like Matthew II: 7-I9 and Luke 7:24-35 to the account of Matthew I I : 2-6 and par.? Would Jesus have spoken of John in the terms of Matthew 21: 25-32, had he learned that John reacted unfavourably to the message of chapter i I ?

In all probability John was re-established in his original belief. If so, not only is John to be 'in' the future Kingdom; he now 'receives' the Kingdom as Jesus presents it. He is already one of the 'happy' (Mt. I I : 6).

How then is Matthew I I : I I to be understood? O. Cullmann renders the verse: 'He who is less [or, younger: namely Jesus] is greater than he [John] in the kingdom of heaven.' 28 In Cullmann's view the saying 'was certainly preserved to serve as a reply to the chronological argument utilized by champions of the Baptist sect'. ${ }^{29}$ However, we may not attribute such an intention (or anything

${ }^{24}$ Mk. I : I4 f., and Dodd, ibid., pp. 292 f.

${ }^{25} \mathrm{Cf}$. 'Gospel and Judgment in the preaching of John the Baptist', Tyndale House Bulletin, XIII, r963.

${ }^{26}$ Jesus and the Origins of Christianity (Harper, r96o), p. 279.

27 Ibid., p. 278.

28 The Early Church (S.C.M., 1956), p. 180.

29 Loc. cit. 
approaching it) to Jesus, or even to the Christians responsible for the source which both Matthew and Luke employ at this point. ${ }^{30}$

The contrast of the verse is really drawn, not between John and 'the least' in the Kingdom, but between 'the Kingdom of men' and 'the Kingdom of God'. ${ }^{31}$ If all belong to the former, only some belong to the latter. And the meanest ${ }^{32}$ citizen of the latter kingdom is greater than the greatest of the former-not because of superior merit (merit he may lack completely), but simply because he is a citizen of the Kingdom of God. In the words of R. Schnackenburg: 'In human effort and in his prophetic function on earth John is the greatest, but everyone who is allowed a share in God's kingdom (it is not stated, indeed it is improbable, that John is not of their number) experiences an elevation in grace through God (Luke 14: I I) that cannot be achieved by even the mightiest human endeavour.'33

${ }^{30}$ See Scobie, op. cit., p. 201 ; J. A. T. Robinson, 'Elijah, John and Jesus', in Twelve Nerv Testament Studies (S.C.M., I962), p. 49, n. 49; and Dodd, Historical Tradition, pp. 298-300.

${ }^{31}$ In a Johannine context the contrast might be described as between those 'born of woman' and those 'born of God' (Jn. I : I 3; 3:3-6). But the doctrine of the new birth is not found in the Synoptics. Whether John is adapting tradition like that found in Mt. I8: 3 , is another matter ( $c f$. Dodd, Historical Tradition, pp. 358 f.).

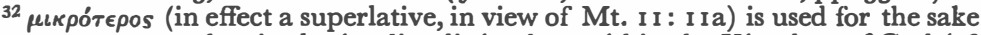
of strong contrast, but it also implies distinctions within the Kingdom of God ( $c f$. Mt. 5: $19 ; 25: 40,45)$. Yet in a more fundamental sense, all who would enter the Kingdom must be-or become-'the least' (Mt. I 8: I-6, ro).

${ }^{33}$ God's Rule and Kingdom (Herder, 1963), p. I34. 